\title{
INDUSTRIAL PLANT FOR PRODUCTION OF Spirulina sp. LEB 18
}

\author{
Lívia da S. Uebel ${ }^{1}$, Jorge A. V. Costa ${ }^{2}$, Adriana C. Olson ${ }^{3}$ and Michele G. de Morais ${ }^{1 *}$ \\ ${ }^{1}$ Universidade Federal do Rio Grande, Escola de Química e Engenharia de Alimentos, Laboratório de Microbiologia e Bioquímica, \\ Rio Grande/RS, Brasil. E-mail: michele.morais@pq.cnpq.br \\ ${ }^{2}$ Universidade Federal do Rio Grande, Escola de Química e Engenharia de Alimentos, Laboratório de Engenharia Bioquímica, \\ Rio Grande/RS, Brasil. \\ ${ }^{3}$ Olson Nutrição, Camaquã/RS, Brasil.
}

(Submitted: May 27, 2017 ; Revised: October 3, 2017 ; Accepted: November 10, 2017)

\begin{abstract}
Biorefineries based on microalgae produce biofuels and co-products with added value. Microalgae mainly require water, carbon dioxide and sunlight for growth. The bioproducts of the cultivation of these microorganisms can be fully used in a microalgae photobiorefinery. The objective of this work was to study the behavior of physico-chemical variables and kinetic and biological responses in industrial cultivation of Spirulina sp. LEB 18, aiming at the operation of a microalgal photobiorefinery. The maximum specific growth rate $(0.133 \mathrm{1} / \mathrm{d})$, the minimum generation time $(5.2 \mathrm{~d})$ and maximum productivity $\left(14.9 \mathrm{~g} / \mathrm{m}^{2} . \mathrm{d}\right)$ were obtained in the first $9 \mathrm{~d}$ of microalgae growth. The maximum biomass concentration $(1.64 \mathrm{~g} / \mathrm{L})$ was obtained in $37 \mathrm{~d}$ of cultivation. The highest levels of carbohydrates, proteins and lipids in the biomass were 10.6, 57.0 and $11.7 \%$, respectively. The plant monitoring demonstrated that the microalgae produced biomass with high quality for application as biofuels, energy, health and nutrition human.

Keywords: Cultivation; Microalgae; Nutrients; Raceway.
\end{abstract}

\section{INTRODUCTION}

Biorefineries have emerged as a new concept in converting biomass to high added value product, food, biofuels and/or energy. Thus, the environmental impacts are reduced and the potential of the feedstock can be exploited in a maximized way (Chew et al., 2017).

The versatility of microalgae cultivation systems, on a large scale, makes it possible to relate the concept of photobiorefinery to the different applications of biomass, such as food supplements, feed, biopolymers, biofuels, pharmaceuticals, pigments, chemicals and wastewater treatment with cost reduction. Cultivations can be performed in open or closed systems and are tools for the elucidation of ecological, physiological, biochemical and behavioral processes (Mata et al., 2010). The raceway photobioreactors are the most used and cheapest cultivation system for commercial production of microalgae. In these ponds, microalgae, water and nutrients circulate around the photobioreactor. With rotating blades providing the flow, microalgae are kept suspended in the water and circulated back to the surface at a regular frequency. The ponds are usually kept shallow because the microalgae need to be exposed to sunlight, and sunlight can only penetrate the pond water to a limited depth (Chisti, 2016).

The use of photosynthesis for the primary production of energy, chemicals and food through microalgae cultivation becomes an interesting option due to the conversion efficiency of solar energy into biomass. Spirulina microalgae, belonging to the group of filamentous cyanobacteria, arose more than 3 million years ago, forming the current oxygen atmosphere, and have been important in the regulation of the planetary biosphere. Spirulina is found naturally in lakes or

\footnotetext{
*Corresponding author: Michele G. de Morais - E-mail: michele.morais@pq.cnpq.br
} 
alkaline lagoons and has the capacity to be cultivated on a large scale under uncontrolled environmental conditions (Morais et al., 2008). Spirulina is widely studied because of high nutritional value and the presence of bioactive compounds. This microalgae is certified Generally Recognized as Safe (GRAS) issued by the Food and Drug Administration (FDA) and can be used as food without presenting health risks.

The maximum utilization of the microalgae biomass depends on the definition of appropriate operation and design variables, especially the increase in scale and energy consumption. In addition, appropriate methods must be established to obtain the desired fractions of the feedstock, followed by characterization and in some cases purification. Besides, the water used in cultivation of Spirulina is important for biomass quality. All of these details add complexity to the process and this complexity increases with the required efficiency.

Both the microalgae growth kinetic parameters and the biomass composition are influenced by physicalchemical, nutritional and operational variables during production. The objective of this work was to study the behavior of physico-chemical variables and kinetic and biological responses in industrial cultivation of Spirulina sp. LEB 18, aiming at the operation of a microalgal photobiorefinery.

\section{MATERIALS AND METHODS}

\section{Microorganism and Cultivation Medium}

The inoculum of Spirulina sp. LEB 18, isolated from Lagoa Mangueira, located in Santa Vitória do Palmar, Rio Grande do Sul, Brazil (Morais et al., 2008) was maintained in Zarrouk medium (Zarrouk, 1966) and adapted to the environmental conditions of the southern region of Brazil. According to Rosa et al. (2015), for increasing growth rate and productivity Zarrouk medium diluted 50\% was used.

\section{Photobioreactors and Growing Conditions}

The cultivation was carried out in the Olson Nutrição industry ( $30^{\circ} 50^{\prime} 23^{\prime \prime}$ south, $51^{\circ} 45^{\prime} 54^{\prime \prime}$ west), located in Camaquã, Rio Grande do Sul, Brazil. The industry has 5 raceway photobioreactors with working volumes between 550 and $26000 \mathrm{~L}$ arranged in a greenhouse covered by a transparent polyethylene film under uncontrolled conditions. The cultivation started in a batch mode, with biomass concentration of $0.30 \mathrm{~g} / \mathrm{L}, \mathrm{pH} 9.5$ and volume of $9600 \mathrm{~L}$. Subsequently, it was maintained in semi-continuous mode, with a cut-off concentration of $0.65 \mathrm{~g} / \mathrm{L}$, volume of 17500 $\mathrm{L}$; the evaporation was controlled daily by addition of water treated with sodium hypochlorite $(2 \mathrm{ppm})$ and continuous agitation performed by rotating blades with speed of $7 \mathrm{rpm}$.
The results were obtained from monitoring one of the photobioreactors with a working volume of $26000 \mathrm{~L}\left(26.2 \times 3.6 \times 0.50 \mathrm{~m}^{3}\right)$, during the months from February to December of 2016, totaling 325 d of cultivation. The cultivation started on February 10, 2016, from inoculum of Spirulina sp. LEB 18 cultured in photobioreactors with 550 and $2300 \mathrm{~L}$ of working volume. In order to analyze the carbohydrate, protein, moisture, ashes, lipids, fatty acids, phycocyanin and amino acid contents, the biomass was collected with medium recycle, at the cultivation times of 80,190 and $250 \mathrm{~d}$, totaling 3 samples.

In the collection carried out in the industry, the suspension containing the Spirulina sp. LEB 18 microalgae was pumped to a chamber type filter press (Eco Tecnologia Ambiental Ltda. ECO - FP HSA 400 x $400-10 / 20$, Brazil) by a pneumatic pump (Netzsck N10 Plastic, Brazil). During filtration the cultivation medium was returned to the photobioreactor and subsequently the microalgae biomass samples retained in the filter press were frozen at $-80{ }^{\circ} \mathrm{C}$ (Indrel IULT 90-D, Brazil) and lyophilized (Liotop L108, Brazil).

On the days $0,12,41,50,64,93,104,156,168$, 222, 253 and $295 \mathrm{~d}$ additions of Zarrouk medium to the cultivation of Spirulina sp. LEB 18 were realized. The medium additions occurred with a gradual increase of the cultivation volume and, according to the collections made by Olson Nutrição, $2 \mathrm{~kg}$ of carbon source is required to produce $1 \mathrm{~kg}$ of biomass. On the days $0,50,64$ and $168 \mathrm{~d} 50 \%$ dilution was used in the Zarrouk cultivation medium for increasing the growth rate and productivity; at the other times no dilution was performed of the added medium.

\section{Analytical Determinations}

The biomass concentration, cultivation $\mathrm{pH}$, luminosity, and ambient and cultivation medium temperatures were monitored daily. The biomass concentration was determined by measuring the optical density of the cultivation in a spectrophotometer at $670 \mathrm{~nm}$ (Biospectro SP-220, Brazil), using a standard curve that correlates optical density with dry mass of the microalgae. The $\mathrm{pH}$ measurements were performed with a digital $\mathrm{pH}$ meter (Quimis Q400HM, Brazil). The photobioreactor luminosity was measured on the surface of the cultivation with a digital luximeter (Instrutherm LD-300, Brazil) and the temperature inside of the greenhouse and cultivation was monitored (Thermometer, United States) with registration of minimum and maximum temperatures.

The concentrations of total carbon, phosphate and nitrate in the cultivation medium were evaluated every $5 \mathrm{~d}$. For these determinations the cells were separated from the medium by filtration. The total dissolved inorganic carbon was calculated by summing the chemical species at equilibrium $\mathrm{CO}_{2(\mathrm{aq})} \leftrightarrows \mathrm{H}_{2} \mathrm{CO}_{3} \leftrightarrows$ $\mathrm{HCO}_{3}^{-} \leftrightarrows \mathrm{CO}_{3}^{2-}$. The concentration of each chemical 
species at equilibrium was determined by direct measurement of the cultivation $\mathrm{pH}$ (Eq. 1) and the total alkalinity obtained by titration with $0.1 \mathrm{~N}$ hydrochloric acid until the $\mathrm{pH}$ of the cultivation reached 4.3.

$\mathrm{pH}=-\log \left[\mathrm{H}^{+}\right]$

The phosphate concentration was determined by colorimetric analysis (PhosVer 3, Hach) at a wavelength of $880 \mathrm{~nm}$. The nitrate concentration was determined using a colorimetric method proposed by Cataldo et al. (1975) at a wavelength of $410 \mathrm{~nm}$.

The yield coefficients $\left(\mathrm{Y}_{\mathrm{X} / \mathrm{S}}, \mathrm{g} / \mathrm{g}\right)$ of carbon and nitrate in biomass were calculated according to Equation 2, where $\mathrm{X}$ corresponds to the concentration of biomass $(\mathrm{g} / \mathrm{L})$ in final time $(\mathrm{d}), \mathrm{X}_{0}(\mathrm{~g} / \mathrm{L})$ the concentration of biomass at initial time $\left(\mathrm{t}_{0}\right)(\mathrm{d}), \mathrm{S}_{0}$ $(\mathrm{g} / \mathrm{L})$ the initial nutrient concentration and $\mathrm{S}(\mathrm{g} / \mathrm{L})$ the final nutrient concentration. The calculations were performed considering that the final biomass had $35.28 \%$ carbon and 6.54\% nitrogen (Monod, 1949).

$\mathrm{Y}_{\mathrm{X} / \mathrm{S}}=\frac{\left(\mathrm{X}-\mathrm{X}_{0}\right)}{\left(\mathrm{S}_{0}-\mathrm{S}\right)}$

\section{Determination of Kinetic Parameters}

The specific growth rate $(\mu, 1 / \mathrm{d})$ was determined by means of the exponential regression of the $\log$ phase of the curve of each growth cycle. The productivity $(\mathrm{P}$, $\mathrm{mg} / \mathrm{L} . \mathrm{d})$ was obtained according to Equation 3, where $\mathrm{X}$ corresponds to the concentration of biomass $(\mathrm{g} / \mathrm{L})$ at time $t(d)$ and $X_{0}(g / L)$ the concentration of biomass at time zero $\left(\mathrm{t}_{0}\right)(\mathrm{d})$. Also determined were the maximum biomass concentration $\left(\mathrm{X}_{\max }, \mathrm{g} / \mathrm{L}\right)$, the maximum productivity $\left(\mathrm{P}_{\max }, \mathrm{g} / \mathrm{L} . \mathrm{d}\right)$ and the generation time $\left(\mathrm{t}_{\mathrm{g}}\right.$, d) (Eq. 4).

$$
\mathrm{P}=\frac{\left(\mathrm{X}-\mathrm{X}_{0}\right)}{\left(\mathrm{t}-\mathrm{t}_{0}\right)}
$$

$$
\mathrm{t}_{\mathrm{g}}=\ln \frac{2}{\mu}
$$

\section{Biomass Characterization}

\section{Carbohydrates and Proteins}

The amount of $50 \mathrm{mg}$ of each sample of Spirulina sp. LEB 18 was rehydrated with $100 \mathrm{~mL}$ of distilled water and submitted to an ultrasonic probe (Cole Parmer CV18, United States) for 10 min in $10 \mathrm{~s}$ pulses and the microalgae extract was obtained. From this extract carbohydrates were analyzed according to Dubois et al. (1956), using glucose as standard, and proteins by the method proposed by Lowry et al. (1951), using albumin as standard.
Moisture and Ashes

The moisture content was obtained by mass loss of Spirulina sp. LEB 18 biomass when submitted to 105 ${ }^{\circ} \mathrm{C}$ in an oven (Fanen 515, Brazil) until constant mass. Ash content was obtained by incineration of Spirulina sp. LEB 18 biomass in a muffle (Indústria e Comércio de Fornos Magnu's Ltda., Brazil) at $550{ }^{\circ} \mathrm{C}$ for $8 \mathrm{~h}$.

\section{Lipids and Fatty Acids Profile}

The lipids were quantified in the biomass samples of Spirulina sp. LEB 18 using the method of Folch et al. (1957). Subsequently, the lipids were esterified by the method of Metcalfe et al. (1966). The esterification consisted of saponification with $0.5 \mathrm{~mol} / \mathrm{L}$ potassium hydroxide in methanol and the esterification reaction with methanol was catalyzed by boron trifluoride. The solvent was evaporated and the sample solubilized in dichloromethane for analysis by gas chromatography.

The separation and quantification of the esterified fatty acids mixture were performed using a gas chromatograph (Shimadzu 2010 Plus, Japan), equipped with split/splitless injector, RTX $\AA-1$ capillary column (30 m x $0.25 \mathrm{~mm} \times 0.25 \mu \mathrm{m}$ ) and flame ionization detector. The carrier gas was helium at a flow rate of $1.25 \mathrm{~mL} / \mathrm{min}$. The injector and detector temperatures were adjusted to $260{ }^{\circ} \mathrm{C}$, the volume injected being 1 $\mu \mathrm{L}$. The chromatographic separation conditions were initial column temperature $50^{\circ} \mathrm{C}$, rising to $200{ }^{\circ} \mathrm{C}$ at 6 ${ }^{\circ} \mathrm{C} / \mathrm{min}$, remaining at this temperature for $4 \mathrm{~min}$. In the second temperature variation, the temperature increase rate was $2{ }^{\circ} \mathrm{C} / \mathrm{min}$ to $240{ }^{\circ} \mathrm{C}$, remaining for $10 \mathrm{~min}$. The comparison of retention times with methyl esters of standards was used to identify the fatty acid profile of the samples and quantified by area normalization.

\section{Phycocyanin}

The samples of Spirulina sp. LEB 18 biomass $(0.08 \mathrm{~g})$ were immersed in $1 \mathrm{~mL}$ of $0.1 \mathrm{~mol} / \mathrm{L}$ sodium phosphate buffer ( $\mathrm{pH}$ 6.9) and kept in an ultrasonic bath (Quimis Q3350, Brazil) for 15 min for phycocyanin extraction. The samples were then centrifuged (Hitachi Himac CT6EL, Japan) at $6000 \times \mathrm{g}$ for $10 \mathrm{~min}$, and the supernatant collected. Each sample was submitted to two successive extractions, in the same way as the first one. Aliquots of the 3 supernatants were mixed, and immediately the absorbance at wavelength reading, 620 and $652 \mathrm{~nm}$ was measured in a spectrophotometer (Shimadzu UVmini-1240, Japan). The concentration of phycocyanin was obtained according to Bennett and Bogorad (1973) and expressed in $\mathrm{mg} / \mathrm{g}$ of sample.

\section{Amino Acid Composition}

The determination of the amino acid composition was performed according to Streit (2014), from the hydrolysis of the Spirulina sp. LEB 18 biomass with $0.6 \mathrm{~mL}$ of $6 \mathrm{~mol} / \mathrm{L}$ hydrochloric acid in an oven (Fanen 
515, Brazil) at $105{ }^{\circ} \mathrm{C}$ for $24 \mathrm{~h}$. Subsequently, the samples were resuspended with $5 \mathrm{~mL}$ of Milli-Q water (Millipore Simplicity UV, United States), submitted to ultrasonic bath (Quimis Q3350, Brazil) for $1 \mathrm{~min}$, after vortexing (Warmnest VX-28, Brazil) for $30 \mathrm{~s}$, filtered, frozen at $-80{ }^{\circ} \mathrm{C}$ (Indrel IULT 90-D, Brazil) and lyophilized (Liotop L108, Brazil).

The lyophilized material was resuspended in $500 \mu \mathrm{L}$ of mobile phase prior to injection into the chromatograph. The samples were injected in a high performance liquid chromatograph (Shimadzu LC20AD, Japan), equipped with a Shimpack Amino-Na column $(6.0 \mathrm{~mm} \times 100 \mathrm{~mm})$, maintained at a constant temperature of $60{ }^{\circ} \mathrm{C}$, fluorescence detector and post column derivatization with xenon lamp. Amino acid detection was performed at the wavelengths of $450 \mathrm{~nm}$ and $350 \mathrm{~nm}$ for emission and excitation, respectively, from the colored complex formed in the derivatization between $50 \mu \mathrm{L}$ aliquots of the hydrolyzate and orthophthalaldehyde aliquot. The amino acids quantification was based on the comparison of the chromatograms generated from the amino acids of the samples and standards of known concentration. The standards were derivitized under the same conditions and at the same time as the samples.

\section{Statistical Analysis}

The means of the responses obtained were evaluated by analysis of variance, followed by the Tukey test, with a confidence interval of $95 \%(\mathrm{p} \leq 0.05)$.

\section{RESULTS AND DISCUSSION}

\section{Monitoring the Cultivation}

Concentration of Spirulina sp. LEB 18 in the Industrial Plant

The growth curves showed a linear increase of the biomass concentration in each cycle (Fig. 1a). The biomass concentration varied from 0.06 to $1.64 \mathrm{~g} / \mathrm{L}$ and the maximum concentration was obtained in $37 \mathrm{~d}$ of cultivation. The maximum temperature of the day was $35.5^{\circ} \mathrm{C}$, which is part of the optimum temperature range for the growth of Spirulina microalgae.

The cycle of decrease of the biomass concentration occurred from 50 to $150 \mathrm{~d}$ of cultivation, due to the occurrence of cold and cloudy days, conditions typical of the winter season in the southern hemisphere in the period of the analyzed year. These climatic conditions reduced luminosity (Fig. 1c) and temperature (Fig. 2) of the cultivation and probably influenced the Spirulina sp. LEB 18 growth. The maximum biomass concentration obtained in the industrial plant was higher than that determined by Morais et al. (2009), which was $1.24 \mathrm{~g} / \mathrm{L}$ in cultivation of Spirulina sp. LEB 18 on a pilot scale, with a maximum daytime temperature around $40^{\circ} \mathrm{C}$.
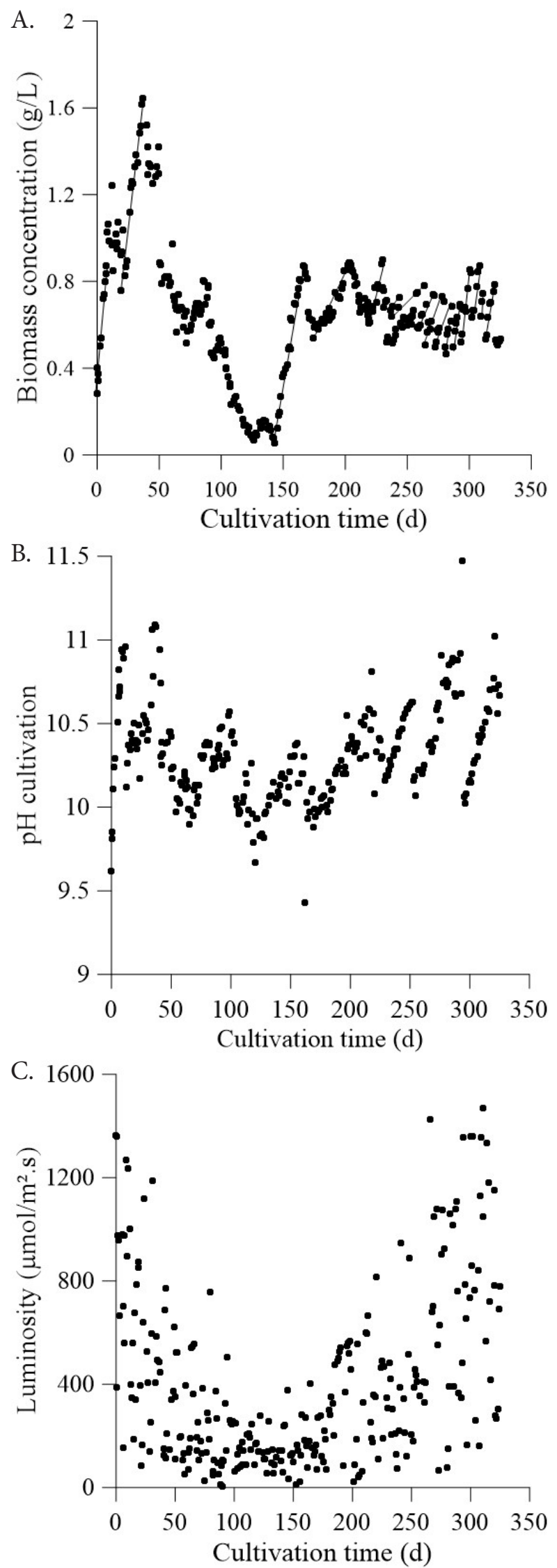

Figure 1. Variation of biomass concentration (a), $\mathrm{pH}$ (b) and luminosity (c) of Spirulina sp. LEB 18 cultivation in the industrial plant. 


\section{pH of Microalgae Cultivation}

The $\mathrm{pH}$ of Spirulina sp. LEB 18 cultivation in the industrial plant remained between 9.4 and 11.5 (Fig. 1b). Morais et al. (2009), in a pilot plant production of Spirulina sp. LEB 18 in the south of Brazil, obtained a cultivation $\mathrm{pH}$ between 9.0 and 10.7. According to Kumar et al. (2010), some microalgae have high productivity when maintained at alkaline $\mathrm{pH}$ between 10.0 and 11.0. In addition, high $\mathrm{pH}$ may be beneficial for large-scale cultivation because it difficult the growth of pathogenic microorganisms and other microalgae.

According to Pelizer et al. (2003), the optimum $\mathrm{pH}$ range for Spirulina growth is 9.5 to 10.5 and the cultivation $\mathrm{pH}$ is maintained in this range due to the carbon source (bicarbonate) present in the Zarrouk medium composition. The increase in $\mathrm{pH}$ can occur
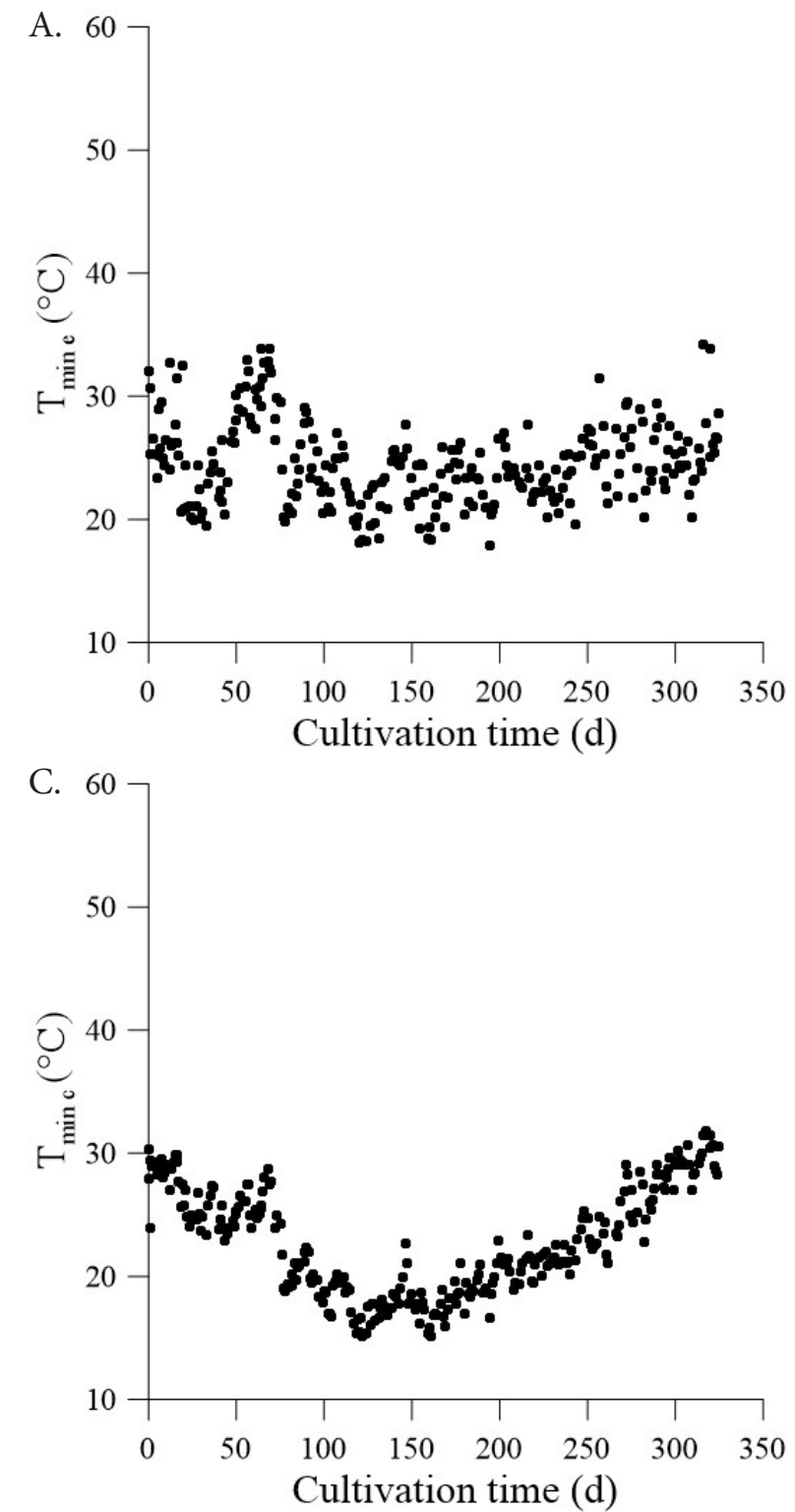

as a function of the autotrophic metabolism of the microalga, where the bicarbonate ion of the medium dehydrates forming carbon dioxide $\left(\mathrm{CO}_{2}\right)$ for photosynthesis and hydroxide ions $\left(\mathrm{OH}^{-}\right)$, while the reduction in $\mathrm{pH}$ occurs due to the release of $\mathrm{CO}_{2}$ from respiration.

In this way and from Figure 1, the cycles of increase of the cultivation $\mathrm{pH}$ in the industrial plant were related with the microalgae growth and consumption of the carbon source, consequently, the $\mathrm{pH}$ reductions occurred with the additions of Zarrouk medium. As there was a reduction in microalgae growth (Fig. 1a) due to the low temperature of the cultivation (Fig. 2), during the winter in the southern hemisphere in the analyzed period, it was possible to observe stabilization in the nutrient consumption (Fig. 3) and thus the $\mathrm{pH}$ remained below 10.5 .
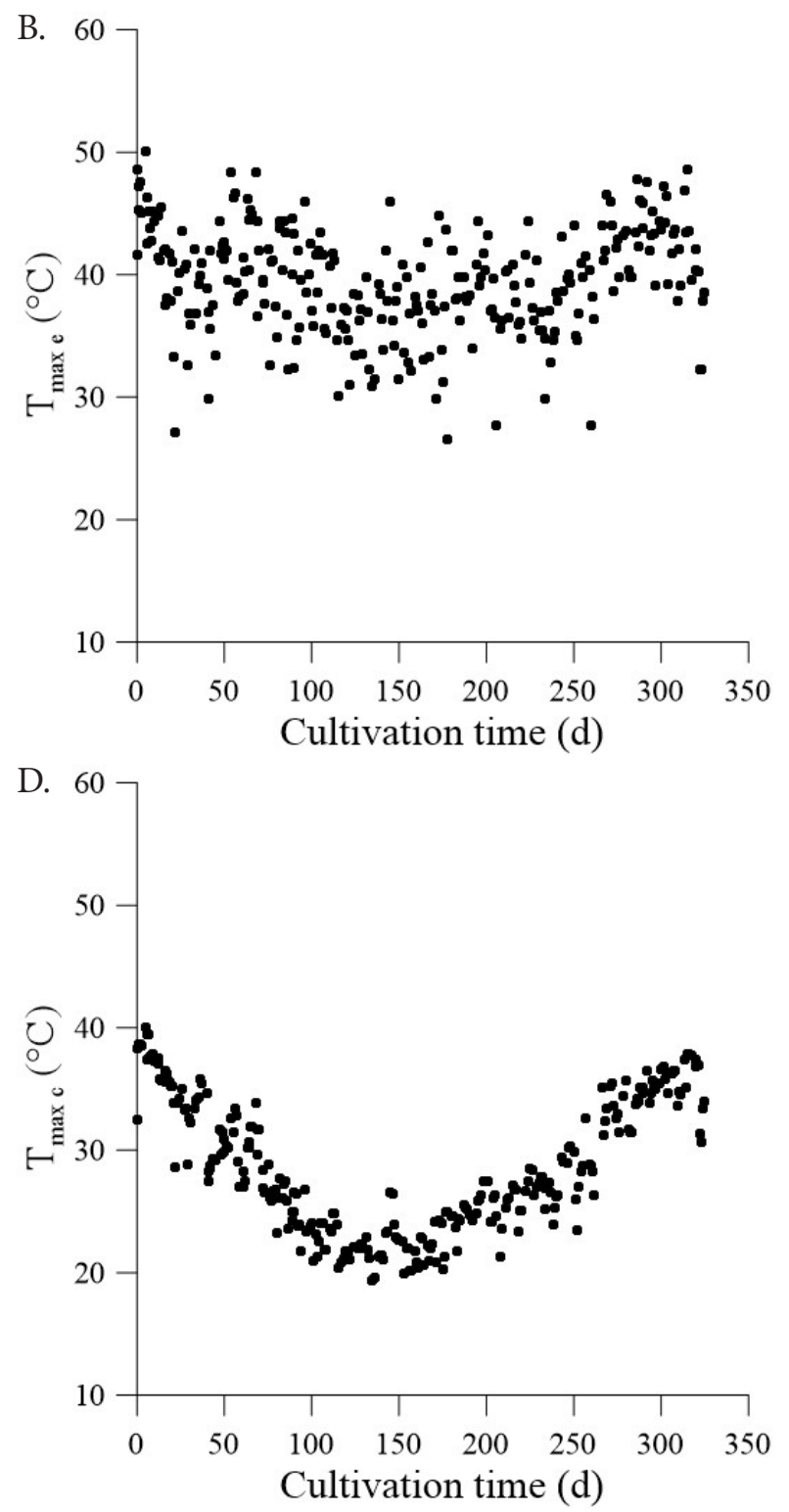

Figure 2. Variation of minimum (a) and maximum (b) temperatures inside of the greenhouse and minimum (c) and maximum (d) temperatures of Spirulina sp. LEB 18 cultivation in the industrial plant. 

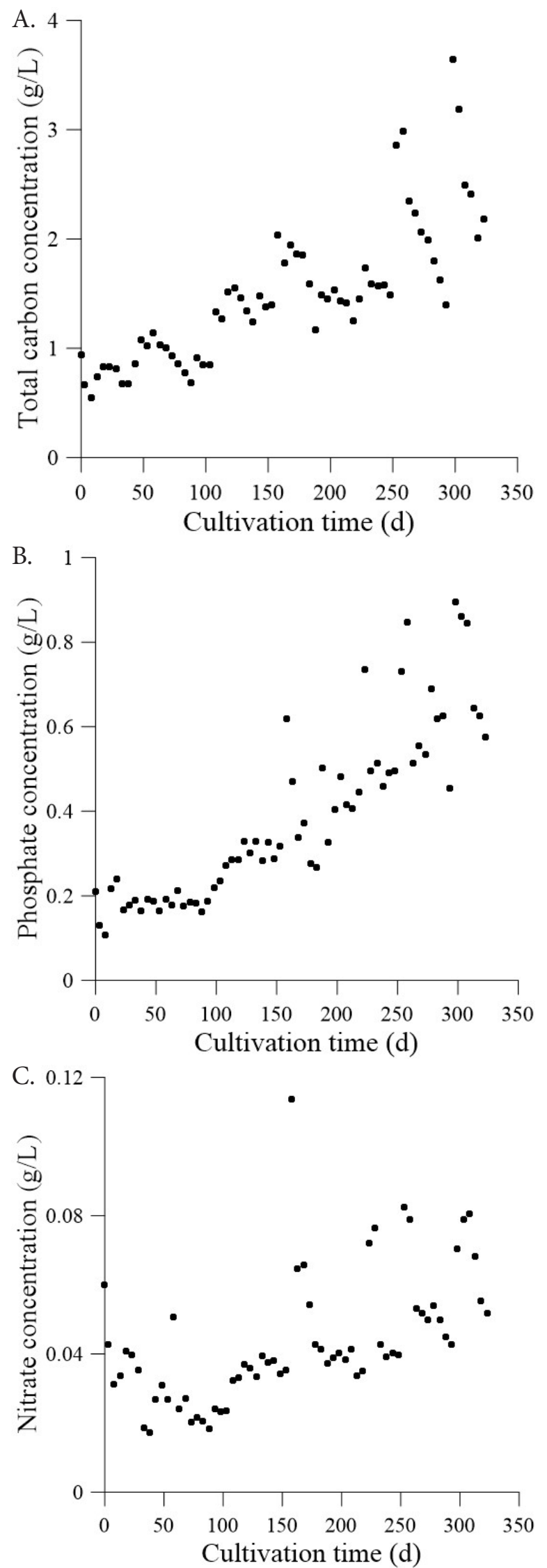

Figure 3. Variation of the concentration of total carbon (a), phosphate (b) and nitrate (c) of Spirulina sp. LEB 18 cultivation in the industrial plant.
Luminosity in The Microalgae Cultivation Surface

The luminosity of Spirulina sp. LEB 18 cultivation in the covered greenhouse exposed to environmental conditions remained between $11 \mu \mathrm{mol} / \mathrm{m}^{2} . \mathrm{s}(89 \mathrm{~d})$ and $1469 \mu \mathrm{mol} / \mathrm{m}^{2} . \mathrm{s}(310 \mathrm{~d})($ Fig. $1 \mathrm{c})$. A reduction of luminosity was observed from 50 to $150 \mathrm{~d}$ of cultivation, due to the occurrence of cloudy days, which possibly influenced the microalgae growth.

Spectrum and light intensity are the factors that affect the phototrophic performance of algae. In relation to the present study, in view of the photobiorefinery in the industrial plant, sunlight is the main source of energy, which saves money on the use of artificial lighting sources used by other types of cultivation. In addition, the greenhouse microalgae cultivation is disposed in a rural area, where there are no buildings which may cause shading.

Minimum and Maximum Temperatures Inside of the Greenhouse and Cultivation in the Industrial Plant

Minimum temperatures inside of the greenhouse $\left(\mathrm{T}_{\text {min e }}\right)$ remained between $17.9{ }^{\circ} \mathrm{C}(194 \mathrm{~d})$ and 34.2 ${ }^{\circ} \mathrm{C}(316 \mathrm{~d})$ and maximum temperatures $\left(\mathrm{T}_{\max } \mathrm{e}\right)$ between $26.6{ }^{\circ} \mathrm{C}(178 \mathrm{~d})$ and $50.1{ }^{\circ} \mathrm{C}(5 \mathrm{~d})$. Minimum temperatures of the cultivation $\left(\mathrm{T}_{\min \mathrm{c}}\right)$ remained between $15.1{ }^{\circ} \mathrm{C}(122$ and $161 \mathrm{~d})$ and $31.8{ }^{\circ} \mathrm{C}(317$ d) and maximum temperatures $\left(\mathrm{T}_{\max } \mathrm{c}\right)$ between 19.4 ${ }^{\circ} \mathrm{C}(134 \mathrm{~d})$ and $40.0{ }^{\circ} \mathrm{C}(5 \mathrm{~d})$ (Fig. 2). Temperature is one of the main factors that alters cellular morphology and physiology, as well as byproducts of microalgae biomass. At elevated temperature there is usually an increase in the metabolism of microalgae due to increased enzymatic activity.

Although the strain of Spirulina sp. LEB 18 cultured in industrial plant was originally isolated from the Mangueira Lagoon and previously adapted to the environmental conditions of the southern region of Brazil. In 50 to $150 \mathrm{~d}$ of cultivation there was a reduction of the biomass concentration (Fig. 1a), possibly as a function of the decrease of the temperature during the winter. However, there was no cell death and thus the importance is demonstrated of performing a previous stage of microalgae adaptation and cultivation of regional microorganisms to maintain industrial production during all seasons.

In addition, arranging the cultivation in a covered greenhouse to maintain the highest temperatures during the winter was observed to provide temperatures closer to the optimum growth temperature of the Spirulina microalgae, which is $35-37{ }^{\circ} \mathrm{C}$. Richmond (1990) observed that during outdoor cultivation the minimum temperature for Spirulina platensis growth was approximately $18{ }^{\circ} \mathrm{C}$ and also that the cultivation can be rapidly injured when the maximum temperature of the day is below $12{ }^{\circ} \mathrm{C}$. 
Concentration of Total Carbon, Phosphate and Nitrate in Microalgae Cultivation

As shown in Figure 3 it is possible to relate the peaks of increase of the carbon, phosphate and nitrate concentration to the additions of Zarrouk medium in the cultivation. The concentrations of total carbon, phosphate and nitrate in the cultivation medium of Spirulina sp. LEB 18 in the industrial plant ranged from 0.55 to $3.65 \mathrm{~g} / \mathrm{L}, 0.11$ to $0.89 \mathrm{~g} / \mathrm{L}$ and 0.02 to $0.11 \mathrm{~g} / \mathrm{L}$, respectively. The monitoring allowed us to relate the microalgae growth cycles in the industrial plant (Fig. 1a) with the intervals of consumption and reduction of total carbon, phosphorus and nitrogen sources in Zarrouk cultivation medium (Fig. 3).

Carbon makes up a large quantity of organic molecules, such as proteins, carbohydrates and lipids. In addition, to provide conditions of high alkalinity to the Spirulina microalgae, which is important to prevent contamination of the cultivation, a high concentration of carbonate is used, which is the source of carbon in the medium.

Possibly, as the cultivation was maintained in semicontinuous mode, the phosphorus source was added in a larger amount than the Spirulina sp. LEB 18 requires. Therefore, there was no complete consumption of the nutrient before the new addition of Zarrouk cultivation medium. According to Powell et al. (2008), microalgae have the capacity to store phosphorus as polyphosphate in intracellular form, through which they absorb it in an amount greater than that required for their immediate growth. Thus, in order to reduce costs with the addition of excess nutrients in the medium, it is interesting to carry out a study of the behavior of the microalgae in the industrial plant in cultivation with reductions of 25 and $50 \%$ in the source of phosphorus in the Zarrouk cultivation medium in the periodicity of monthly addition.

The nitrogen source is essential for microalgae growth, being the constituent of nucleic acids and proteins. Silva (2016) in cultivation of Spirulina sp. LEB 18 on a laboratory scale in Zarrouk medium determined a nitrate concentration similar to the present study (between 0.12 and $0.01 \mathrm{~g} / \mathrm{L}$ ). In the referenced study, the total carbon concentration varied from 2.1 to $1.1 \mathrm{~g} / \mathrm{L}$ and the phosphate remained practically constant, around $0.3 \mathrm{~g} / \mathrm{L}$, from the beginning to the end of the $20 \mathrm{~d}$ experiment.

For microalgal cultures, the growth rate and yield coefficients are equally important. The yield coefficients defined the amount of biomass of Spirulina sp. LEB 18 obtained per unit mass of the nutrient consumed for microalgal growth. The yield coefficients in biomass for annual cultivation were 0.06 and $1.76(\mathrm{~g} / \mathrm{g})$ for carbon and nitrate, respectively. Thus, it was observed that these determinations are not only necessary to evaluate the efficiency of the microalgal culture, but also allow obtaining economic data of the process.

Kinetic Parameters of Spirulina sp. LEB 18 Growth

The specific rate of growth ranged from 0.015 to 0.133 1/d (Table 1). Cycles that had higher specific growth rates remained less time in the exponential phase. The maximum specific growth rate $(0.1331 / \mathrm{d})$, which differed statistically from the others $(p \leq 0.05)$, was observed in the first days of cultivation and was similar to that determined by Rosa et al. (2015), which was $0.140 \mathrm{1} / \mathrm{d}$ in the first cycle of semi-continuous cultivation of Spirulina in a raceway type bioreactor with a working volume of $5 \mathrm{~L}$, photoperiod of $12 \mathrm{~h}$ light/dark and with addition of Zarrouk medium.

The maximum productivity $\left(14.9 \mathrm{~g} / \mathrm{m}^{2} . \mathrm{d}\right)$ presented a significant difference from the others $(\mathrm{p} \leq 0.05)$ and was obtained in the first $9 \mathrm{~d}$ of growth of Spirulina $\mathrm{sp}$. LEB 18 (Table 1). According to Travieso et al. (2001), the optimum concentration of Spirulina biomass for maximum productivity is 0.5 to $0.7 \mathrm{~g} / \mathrm{L}$. In the present study, the biomass concentration in the first cultivation cycle ranged from 0.3 to $1.0 \mathrm{~g} / \mathrm{L}$. Morais et al. (2009), in a study on the cultivation of Spirulina sp. LEB 18 in a pilot plant with raceway type bioreactors, also observed a decrease in productivity during the cultivation time, which occurred from July, 2005, to August, 2006.

The lowest specific growth rates, the highest generation times and the highest exponential growth times were observed during the winter period, due to the typical conditions of the season, demonstrating the influence of the parameters luminosity and temperature

Table 1. Growth specific rates $(\mu, 1 / \mathrm{d})$, generation times $(\mathrm{tg}, \mathrm{d})$ and productivity $\left(\mathrm{P}, \mathrm{g} / \mathrm{m}^{2} . \mathrm{d}\right)$ of Spirulina sp. LEB 18 cultivation in the industrial plant.

\begin{tabular}{ccccc}
\hline $\begin{array}{c}\text { Growth } \\
\text { cycle }\end{array}$ & $\begin{array}{c}\text { Number } \\
\text { of days } \\
\text { of growth }\end{array}$ & $\begin{array}{c}\boldsymbol{\mu} \\
(\mathbf{1} / \mathbf{d})\end{array}$ & $\begin{array}{c}\mathbf{t g} \\
\mathbf{( d )}\end{array}$ & $\begin{array}{c}\mathbf{P} \\
\left(\mathbf{g} / \mathbf{m}^{\mathbf{2}} . \mathbf{d}\right)\end{array}$ \\
\hline 1 & 9 & $0.133^{\mathrm{i}}$ & $5.2^{\mathrm{a}}$ & $14.9^{\mathrm{d}}$ \\
2 & 15 & $0.044^{\mathrm{cd}}$ & $15.8^{\mathrm{ab}}$ & $3.3^{\mathrm{c}}$ \\
3 & 23 & $0.096^{\mathrm{h}}$ & $7.2^{\mathrm{ab}}$ & $0.2^{\mathrm{ab}}$ \\
4 & 30 & $0.015^{\mathrm{a}}$ & $45.4^{\mathrm{c}}$ & $0.5^{\mathrm{b}}$ \\
5 & 4 & $0.018^{\mathrm{a}}$ & $42.1^{\mathrm{c}}$ & $0.4^{\mathrm{ab}}$ \\
6 & 11 & $0.036^{\mathrm{bc}}$ & $19.3^{\mathrm{b}}$ & $0.4^{\mathrm{ab}}$ \\
7 & 5 & $0.057^{\mathrm{fg}}$ & $12.1^{\mathrm{ab}}$ & $0.3^{\mathrm{ab}}$ \\
8 & 6 & $0.062^{\mathrm{g}}$ & $11.2^{\mathrm{ab}}$ & $0.3^{\mathrm{ab}}$ \\
9 & 5 & $0.047^{\mathrm{de}}$ & $14.7^{\mathrm{ab}}$ & $0.3^{\mathrm{ab}}$ \\
10 & 6 & $0.050^{\mathrm{def}}$ & $13.8^{\mathrm{ab}}$ & $0.3^{\mathrm{ab}}$ \\
11 & 8 & $0.036^{\mathrm{b}}$ & $19.6^{\mathrm{b}}$ & $0.3^{\mathrm{ab}}$ \\
12 & 6 & $0.060^{\mathrm{g}}$ & $11.6^{\mathrm{ab}}$ & $0.2^{\mathrm{a}}$ \\
13 & 6 & $0.056^{\mathrm{fg}}$ & $12.4^{\mathrm{ab}}$ & $0.2^{\mathrm{a}}$ \\
14 & 5 & $0.062^{\mathrm{g}}$ & $11.1^{\mathrm{ab}}$ & $0.2^{\mathrm{a}}$ \\
15 & 7 & $0.063^{\mathrm{g}}$ & $11.0^{\mathrm{ab}}$ & $0.3^{\mathrm{ab}}$ \\
16 & 6 & $0.056^{\mathrm{fg}}$ & $12.4^{\mathrm{ab}}$ & $0.3^{\mathrm{ab}}$ \\
17 & 7 & $0.052^{\mathrm{ef}}$ & $13.4^{\mathrm{ab}}$ & $0.2^{\mathrm{ab}}$ \\
\hline
\end{tabular}

Equal letters in the same column indicate that there is no significant difference $(p>0.05)$ between the cycles. 
on the cultivation of Spirulina sp. LEB 18 in a greenhouse, exposed to uncontrolled conditions (Table 1). After this period, due to the change of the season, an increase of these parameters of the cultivation in the industrial plant was observed (Figs. 1c and 2).

The specific growth rates, generation times and productivies obtained for cycles 12,13, 14, 15 and 16 did not show a significant difference $(\mathrm{p}>0.05)$, demonstrating the periodicity of the weekly collections in the industrial plant, observed in the growth cycles of microalgae with fewer number of days (Fig. 1a). The specific growth rates of the last cycles were similar to that found by Moreira et al. (2016), which was 0.060 $1 / \mathrm{d}$, in cultivation of Spirulina sp. LEB 18 in Zarrouk medium on a laboratorial scale and $20 \%$ renewal rate.

The reduction of the specific growth rate and productivity at each growth cycle may have occurred due to variation in factors such as temperature, $\mathrm{pH}$ and luminosity, since the covered greenhouse is exposed to uncontrolled conditions. The lack of luminosity is due to the presence of cloudy days and winter and also due to the concentration of biomass in the cultivation medium. According to Vonshak et al. (1982), at a concentration of $0.50 \mathrm{~g} / \mathrm{L}, 80 \%$ of the cells are without light at any given time, which also may have limited the light energy absorption for photosynthesis, reducing the microalgae growth rate.

Radmann et al. (2011) studied control cultivation of Spirulina sp. LEB 18 in Zarrouk medium, maintained at room temperature for $40 \mathrm{~d}$, with light intensity promoted by fluorescent lamps and a photoperiod of $12 \mathrm{~h}$ light/dark, in raceway-type bioreactors constructed of acrylic, with a working volume of $5 \mathrm{~L}$ and stirred by rotating blades at $18 \mathrm{rpm}$. The initial biomass concentration of the cultivation was $0.15 \mathrm{~g} / \mathrm{L}$ and evaporation was controlled by daily replenishment with distilled water. According to Table 1, the average productivity $\left(1.3 \mathrm{~g} / \mathrm{m}^{2}\right.$.d) was higher than those found in the referenced study, which yielded productivities between 0.4 and $1.0 \mathrm{~g} / \mathrm{m}^{2} . \mathrm{d}$. The specific growth rate in most cycles of Spirulina sp. LEB 18 cultivated in the industrial plant was higher than that obtained in the referenced study, which was $0.0171 / \mathrm{d}$.

\section{Characterization of Biomass Composition \\ Centesimal Composition}

As shown in Table 2, there was an increase in the carbohydrate content in Spirulina sp. LEB 18 according to the collected samples. However, the samples collected at times 190 and $250 \mathrm{~d}$ of cultivation did not differ statistically $(p>0.05)$. The protein and lipid concentrations of the samples did not show a significant difference $(\mathrm{p}>0.05)$, demonstrating that they were not influenced by the period in which the biomass was collected, being an interesting factor to obtain microalgae biomass with stable nutritional characteristics in all collections and also important for the definition of the bioproducts of the photobiorefinery.

Proteins concentrations (Table 2) were similar to that found by Madkour et al. (2012), in laboratory scale Spirulina experiments, which was $52.9 \pm 0.5 \%$. Carbohydrates contents were lower, while lipids were higher in Spirulina sp. LEB 18 biomass of the industrial plant (Table 2) in relation to those found by Madkour et al. (2012), which were $13.2 \pm 0.6$ and 7.2 $\pm 0.7 \%$, respectively.

The protein and lipid contents of Spirulina sp. LEB 18 biomass of the industrial plant were higher than those determined by Rosa et al. (2015), which were $48.7 \pm 4.1$ and $8.1 \pm 4.8 \%$, respectively, in Spirulina sp. LEB 18 cultured in raceway type bioreactors on a laboratory scale, with continuous agitation performed by rotating blades at $18 \mathrm{rpm}, 30^{\circ} \mathrm{C}$ temperature and 12 $\mathrm{h}$ light/dark photoperiod. The differences in the biomass composition of the cultivation in the industrial plant and the laboratory scale of the reference study may have occurred due to the different operational variables of the experiments, such as agitation, volume of the cultivation medium, photoperiod, temperature and luminosity.

In cultivations with phosphorus concentration limitation, it was observed by Markou et al. (2012) that the protein content was reduced, since phosphorus participates in protein metabolism. As in the present study in the industrial plant there was no limitation of the concentration of phosphorus in the cultivation medium (Fig. 3b), there was no reduction in the protein content (Table 2).

By analyzing the centesimal composition of Spirulina sp. LEB 18, applications of the biocomposites were verified. In this case, carbohydrates can be used as a substrate for the synthesis of bioethanol. Bioethanol has emerged as a source of renewable energy replacing fossil fuels, often associated with environmental pollution, the greenhouse effect and climate change (Ho et al., 2013).

The protein content is important to act as a supplement in food and feed. The biologically active proteins have peptides which confer health

Table 2. Centesimal composition of Spirulina sp. LEB 18 biomass of the industrial plant.

\begin{tabular}{cccccc}
\hline $\begin{array}{c}\text { Cultivation time in biomass } \\
\text { collection (d) }\end{array}$ & Carbohydrates & Proteins & Moisture & Ashes & Lipids \\
\cline { 2 - 6 } & & & $(\%)$ & & $11.1 \pm 0.8^{\mathrm{a}}$ \\
190 & $6.4 \pm 1.2^{\mathrm{b}}$ & $53.8 \pm 6.4^{\mathrm{a}}$ & $7.0 \pm 0.5^{\mathrm{c}}$ & $10.7 \pm 0.1^{\mathrm{a}}$ & $11.7 \pm 0.8^{\mathrm{a}}$ \\
250 & $10.1 \pm 0.9^{\mathrm{a}}$ & $50.4 \pm 4.2^{\mathrm{a}}$ & $6.0 \pm 0.1^{\mathrm{b}}$ & $23.5 \pm 0.1^{\mathrm{c}}$ & $10.5 \pm 0.4^{\mathrm{a}}$ \\
\hline
\end{tabular}

Equal letters in the same column indicate that there is no significant difference $(p>0.05)$ between the samples. 
protection, through their antioxidant potential. These biocomposites contain from 3 to 20 amino acids residues and are formed from hydrolysis of the microalgal biomass as they are inactive within the protein sequence. The hydrolysis of the proteins improves the digestibility of the microalgal biomass, since molecules of lower molecular weight are obtained and are more easily absorbed by the organism (Lisboa et al., 2016).

Lipids have a nutritional function as a source of energy and essential fatty acids for humans derivitized and animal feed. In addition, lipids can be transesterified into biodiesel and also contribute to the production of biosurfactants and biopolymers. Biodiesel from microalgae is a renewable energy alternative to fossil fuels. Moreover, the use of biomass has potential for biodiesel production usually produced from soybean oil. Therefore, microalgae do not compete with food production, being cultivated on infertile land (Delrue et al., 2012). Biosurfactants are an alternative to reduce the use of synthetic surfactants because they are of low toxicity, biodegradable and can be synthesized through the use of renewable resources. These biocomposites are promising because they present applications in drugs, food and environmental protection (Radmann et al., 2015). Biopolymers have similar thermoplastic characteristics to petrochemical polymers and have properties such as biodegradability and biocompatibility with cells and tissues (Martins et al., 2014).

The moisture content of the lyophilized samples (Table 2) was lower than that observed by Oliveira et al. (2009), which was $9.7 \pm 0.8 \%$ in Spirulina cultivated in a bioreactor under uncontrolled conditions and dried in a tray dryer with perpendicular airflow.

The results for the ash analysis of Spirulina sp. LEB 18 presented a significant difference $(p \leq 0.05)$ (Table 2). The values are higher than those found by Morais et al. (2008) (6.7 $\pm 0.1 \%)$ in Spirulina sp. LEB 18 dehydrated after washing, since the biomass was removed after filtration in a filter press, frozen and lyophilized, without the washing step, which justifies the higher ash content in Spirulina sp. LEB 18 biomass of the industrial plant. In addition, it is possible to observe that, after the first collection, the ash percentage increased due to the addition of Zarrouk cultivation medium with monthly frequency and according to the collections made by the industry. In previous periods, the addition of medium occurred according to the increase in biomass concentration and production scheduling and the need to increase the volume of the cultivation medium. Also, 50\% diluted medium was previously used for microalgae growth.

\section{Fatty Acids Profile}

The SFA/UFA contents in Spirulina sp. LEB 18 biomass samples collected at 80, 190 and 250 d of cultivation were $37.4 / 62.8 \%, 43.6 / 56.4 \%$ and $38.7 / 61.2 \%$, respectively (Table 3 ). Unsaturated fatty acids (UFA) exert a protective effect on the body by reducing blood levels of low density proteins (bad cholesterol) and triglycerides, resulting in cardiovascular protection (Brouwer et al., 2010). However, for biodiesel production the presence of saturated fatty acids (SFA), which have a high cetane number and are less prone to oxidation than unsaturated compounds (Canakci, 2007), is important. In this way, the biomass of the industrial plant was characterized for application in human nutrition as well as for biofuels production.

Essential fatty acids are defined as polyunsaturated fatty acids that cannot be synthesized by the body and therefore must be obtained through our diet. These compounds contribute to the prevention and attenuation of heart problems, cholesterol control, immune system activation and cell growth. The fatty acids recognized by the World Health Organization as essential are linoleic, $\alpha$-linolenic, $\gamma$-linolenic and arachidonic acid. As shown in Table 3 , the essential fatty acids linoleic, $\alpha$-linolenic and arachidonic were detected in Spirulina sp. LEB 18 biomass of the industrial plant. According to the data obtained palmitoleic acid was predominant, followed by stearic, oleic and palmitic acids.

Table 3. Fatty acids profile of Spirulina sp. LEB 18 biomass of the industrial plant.

\begin{tabular}{lcccc}
\hline \multirow{2}{*}{ Fatty acid (\%) } & & \multicolumn{3}{c}{ Cultivation time in } \\
biomass collection (d)
\end{tabular}

*: not detected. 
The samples of Spirulina sp. LEB 18 biomass of the industrial plant collected at $190 \mathrm{~d}(1.04 \%)$ and $250 \mathrm{~d}(1.34 \%)$ (Table 3$)$ showed similar values for the percentage of $\alpha$-linolenic acid, which belongs to the $\omega-3$ class, to that detected by Morais and Costa (2008), which was $1 \%$, using $12 \% \mathrm{CO}_{2}$ and 16.8 $\mathrm{g} / \mathrm{L}$ sodium bicarbonate in Spirulina cultivation. In addition, the presence of linoleic acid, which belongs to the $\omega-6$ family, was detected in all Spirulina sp. LEB 18 biomass samples of the industrial plant. The importance of ingestion of foods containing $\omega-3$ and $\omega-6$ occurs because these can help maintain adequate cholesterol levels, contributing to cardiovascular health and to anti-inflammatory action in our body.

All biomass samples of Spirulina sp. LEB 18 of the industrial plant demonstrated the presence of oleic acid, also called $\omega-9$, in amounts greater than $11 \%$ (Table 3). Thus, the nutraceutical action of biomass is again emphasized, since this fatty acid also has an anti-inflammatory action because it has antioxidant properties and thus acts to protect the heart, preventing cancer and cellular aging.

From Table 3, it can be observed that the reduction of the temperature of the cultivation during the winter period can also act positively on the composition of the microalgal biomass. Nitrogen compounds exposed to low temperature may be transformed into energy reserve substances such as lipids. The percentage of 12 fatty acids present in the sample collected at 190 $\mathrm{d}$ of cultivation (winter period) was higher than those detected in samples collected at 80 and $250 \mathrm{~d}$, in which the cultivation was submitted to higher temperatures.

\section{Phycocyanin}

The concentrations of phycocyanin in the Spirulina sp. LEB 18 biomass collected at 80, 190 and $250 \mathrm{~d}$ of cultivation were $25.1 \pm 1.0,8.2 \pm 0.2$ and $17.1 \pm 0.7 \mathrm{mg} / \mathrm{g}$, respectively, and presented a significant difference $(\mathrm{p}$ $\leq 0.05$ ) between the collection periods analyzed. The lower concentration of phycocyanin can be attributed to the winter period, as less luminous intensity was provided during this time interval for the cultivation of the industrial plant in the covered greenhouse under uncontrolled conditions (Fig. 1c). The amount of the accessory pigments is a characteristic that can vary according to microalgal species and that can be photo-stimulated in photoautotrophic cultivations. Phycocyanin, because it has antioxidant capacity, can help prevent diseases and slow cell aging. Moreover, it is used as a coloring agent in food industries, coloring sweets, dairy products and non-alcoholic beverages (Santiago-Santos et al., 2004).

The concentration of phycocyanin of Spirulina sp. LEB 18 biomass of the industrial plant extracted with phosphate buffer, ultrasonic bath and centrifugation are according to Moraes et al. (2011). In the referenced study, phycocyanin extraction methods of Spirulina platensis LEB 52 were compared and concentrations between $0.6 \mathrm{mg} / \mathrm{g}$ (sonication) and $43.7 \mathrm{mg} / \mathrm{g}$ (sonication with glass beads) were obtained by different extractions (chemical, physical and enzymatic).

According to Markou (2014), the production of phycocyanin by microalgae can be improved with the use of specific wavelengths of light. Prates et al. (2015), by means of cultivation with light emitting diodes (LEDs) with wavelength in the red region in different photoperiods, photoestimulated the Spirulina sp. LEB 18 microalgae to concentrate the production of phycocyanin $(154.0 \pm 3.5 \mathrm{mg} / \mathrm{g})$ under conditions of $12 \mathrm{~h}$ fluorescent, $6 \mathrm{~h}$ red LED and $6 \mathrm{~h}$ dark.

Prates et al. (2015) obtained values of $35.9 \pm 0.5$ $\mathrm{mg} / \mathrm{g}$ of phycocyanin in Spirulina sp. LEB 18 cultured in Zarrouk medium with $12 \mathrm{~h}$ fluorescence and $12 \mathrm{~h}$ dark. By means of extraction using water as solvent, shaker shaking and centrifugation, Moraes et al. (2010) found a yield of $82.5 \mathrm{mg} / \mathrm{g}$ phycocyanin. Thus, the concentrations of phycocyanin in Spirulina sp. LEB 18 biomass are lower than those found in the literature, probably due to the extraction and purification steps, which are the most important requirements for obtaining cyanobacteria phycobiliproteins and also because the synthesis of this pigment has not been stimulated.

\section{Amino Acid Composition}

The essential amino acids threonine (in all samples), valine (sample collected at $250 \mathrm{~d}$ of cultivation), methionine (samples collected at 80 and $250 \mathrm{~d}$ of cultivation), isoleucine (in all samples) and leucine (samples collected at 80 and $250 \mathrm{~d}$ of cultivation) found in the Spirulina sp. LEB 18 biomass of the industrial plant presented larger amounts than those required for the adult diet according to the FAO standard (FAO/ WHO, 1991) (Table 4). It is observed that there was a decrease in most of the amino acid concentrations in the biomass sample collected at $190 \mathrm{~d}$ of cultivation, possibly due to the low temperature of the cultivation in the photobioreactor during the winter.

The results obtained for Spirulina sp. LEB 18 biomass of the industrial plant are in accord with Ambrosi et al. (2008), who described the non-essential amino acids present in Spirulina as alanine, arginine, aspartic acid, cystine, glutamic acid, glycine, histidine, proline, serine and tyrosine. In the referenced study, the essential amino acids found in Spirulina biomass were isoleucine, leucine, lysine, methionine, phenylalanine, threonine and valine.

The amounts of aspartic acid, threonine, cysteine and isoleucine in Spirulina sp. LEB 18 biomass of the industrial plant were higher than those detected by Morais et al. (2009). The importance of aspartic acid or aspartate is due to acting as a neurotransmitter, 
Table 4. Amino acid composition of Spirulina sp. LEB 18 biomass of the industrial plant.

\begin{tabular}{|c|c|c|c|c|c|c|c|c|}
\hline \multirow{3}{*}{ Amino acid } & \multirow{2}{*}{\multicolumn{3}{|c|}{$\begin{array}{l}\text { g amino acid/100 g protein } \\
\text { Cultivation time } \\
\text { in biomass collection (d) }\end{array}$}} & \multirow{3}{*}{$\begin{array}{l}\text { FAO/ } \\
\text { WHO } \\
(1991)\end{array}$} & \multirow{2}{*}{\multicolumn{3}{|c|}{$\begin{array}{l}\mathrm{g} \text { amino acid/g biomass } \\
\text { Cultivation time } \\
\text { in biomass collection (d) }\end{array}$}} & \multirow{3}{*}{$\begin{array}{l}\text { Morais } \\
\text { et al. } \\
(2009)\end{array}$} \\
\hline & & & & & & & & \\
\hline & 80 & 190 & 250 & & 80 & 190 & 250 & \\
\hline Aspartic acid & 42.13 & 12.23 & 64.42 & & 24.89 & 14.99 & 22.20 & 9.20 \\
\hline Threonine & 14.22 & 7.96 & 16.64 & 0.90 & 8.40 & 9.76 & 5.73 & 4.87 \\
\hline Serine & 0.23 & 0.06 & 0.52 & & 0.13 & 0.07 & 0.18 & 4.31 \\
\hline Glutamic acid & 0.84 & $<\mathrm{LQ}$ & 4.63 & & 0.50 & $<\mathrm{LQ}$ & 1.60 & 10.70 \\
\hline Proline & 2.80 & 2.95 & 6.22 & & 1.65 & 3.61 & 2.14 & 4.04 \\
\hline Glycine & 3.85 & 2.66 & 3.94 & & 2.28 & 3.26 & 1.36 & 5.17 \\
\hline Alanine & 0.72 & 0.57 & 0.57 & & 0.42 & 0.69 & 0.20 & 6.51 \\
\hline Cysteine & 1.82 & $<\mathrm{LQ}$ & 3.69 & & 1.07 & $<\mathrm{LQ}$ & 1.27 & 0.47 \\
\hline Valine & 0.10 & 0.59 & 1.69 & 1.30 & 0.06 & 0.72 & 0.58 & 4.61 \\
\hline Methionine & 2.75 & 1.44 & 3.41 & 1.70 & 1.62 & 1.76 & 1.18 & 1.64 \\
\hline Isoleucine & 12.24 & 7.30 & 13.67 & 1.30 & 7.23 & 8.95 & 4.71 & 4.36 \\
\hline Leucine & 3.31 & 1.72 & 3.54 & 1.90 & 1.95 & 2.11 & 1.22 & 8.02 \\
\hline Tyrosine & 2.72 & 0.03 & 2.28 & & 1.61 & 0.04 & 0.78 & 3.20 \\
\hline Phenylalanine & 0.94 & 0.92 & 1.51 & 1.90 & 0.56 & 1.13 & 0.52 & 5.75 \\
\hline Histidine & 0.08 & 0.03 & 0.05 & 1.10 & 0.05 & 0.04 & 0.02 & 2.72 \\
\hline Lysine & 0.91 & 0.96 & 1.43 & 1.60 & 0.54 & 1.17 & 0.49 & 2.95 \\
\hline Arginine & 1.40 & 1.71 & 37.21 & & 0.83 & 2.10 & 12.82 & 4.94 \\
\hline
\end{tabular}

LQ: limit of quantification.

threonine can act in the immune system, while cysteine has antioxidant potential and isoleucine is responsible for energy production and control of blood sugar levels.

\section{CONCLUSIONS}

The Spirulina sp. LEB 18 cultivation in the industrial plant allowed us to obtain the maximum biomass concentration of $1.64 \mathrm{~g} / \mathrm{L}$. The maximum specific growth rate $(0.133 \mathrm{l} / \mathrm{d})$, minimum generation time $(5.2 \mathrm{~d})$ and maximum productivity $\left(14.9 \mathrm{~g} / \mathrm{m}^{2} . \mathrm{d}\right)$ were obtained in the first $9 \mathrm{~d}$ of growth. The highest levels of carbohydrates, proteins and lipids in the biomass were $10.6,57.0$ and $11.7 \%$, respectively. The bioproducts with applications as biofuels, energy, health and nutrition demonstrate the potential of the microalgae for the operation of a photobiorefinery, expanding the technological and economic frontiers for the use of biomass as a renewable and sustainable feedstock.

\section{ACKNOWLEDGEMENTS}

The authors thank Olson Nutrição, Coordination for the Improvement of Higher Education Personnel, National Council for Scientific and Technological Development, and Ministry of Science, Technology, Innovation and Communications.

\section{REFERENCES}

Ambrosi, M.A., Reinehr, C.O., Bertolin, T.E., Costa, J.A.V. and Colla, L.M., Propriedades de saúde da microalga Spirulina spp., Revista de Ciências Farmacêuticas Básica e Aplicada, 29, 109-117 (2008).
Bennett, A. and Bogorad, L., Complimentary chromatic adaptation in a filamentous blue-green alga, Journal of Cell Biology, 2, 419-435 (1973). https://doi.org/10.1083/jcb.58.2.419

Brouwer, I.A., Wanders, A.J. and Katan, M.B., Effect of animal and industrial trans fatty acids on HDL and LDL cholesterol levels in humans A quantitative review. PLoS One, 5, 1-9 (2010). https://doi.org/10.1371/journal.pone.0009434

Canakci, M., The potencial of restaurant waste lipids as biodiesel feedstocks, Bioresource Technology, 98, 183-190 (2007). https://doi.org/10.1016/j. biortech.2005.11.022

Cataldo, D.A., Haroon, M., Schrader, L.E. and Youngs, V.L., Rapid colorimetric determination of nitrate in plant tissue by nitration of salicylic acid, Communications in Soil Science and Plant Analysis, 6, 71-80 (1975). https://doi. org $/ 10.1080 / 00103627509366547$

Chew, K.W., Yap, J.Y., Show, P.L., Suan, N.H., Juan, J.C., Ling, T.C., Lee, D. and Chang, J., Microalgae biorefinery: high value products perspectives, Bioresource Technology, 229, 53-62 (2017). https:// doi.org/10.1016/j.biortech.2017.01.006

Chisti, Y., Large-scale production of algal biomass: raceway ponds. In: Bux, F., Chisti, Y. (Eds.), Algae Biotechnology: Products and Processes, Springer, New York (2016). https://doi.org/10.1007/978-3319-12334-9_2

Delrue, F., Setier, P.A., Sahut, C., Cournac, L., Roubaud, A., Peltier, G. and Froment, A.K., An Economic, sustainability, and energetic model of biodiesel production from microalgae, Bioresource Technology, 111, 191-200 (2012). https://doi. org/10.1016/j.biortech.2012.02.020 
Dubois, M., Gilles, K., Hamilton, J., Rebers, P. and Smith, F., Colorimetric method for determination of sugars and related substances, Analytical Chemistry, 28, 350-356 (1956). https://doi. org/10.1021/ac60111a017

FAO/WHO - Food and Agricultural Organization/ World Health Organization, Protein quality evaluation, Food and Agricultural Organization of the United Nations, Roma (1991).

Folch, J., Lees, M. and Stanley, G.H.S., A simple method for the isolation and purification of total lipides from animal tissues, Journal of Biological Chemistry, 226, 497-509 (1957).

Ho, S.H., Huang, S.W., Chen, C.Y., Hasunuma, T., Kondo, A. and Chang, J.S., Bioethanol production using carbohydrate-rich microalgae biomass as feedstock, Bioresource Technology, 135, 191-198 (2013). https://doi.org/10.1016/j. biortech.2012.10.015

Kumar, A., Ergas, S., Yuan, X., Sahu, A., Zhang, Q., Dewulf, J., Malcata, F. X. and Langenhove, V.H., Enhanced $\mathrm{CO}_{2}$ fixation and biofuel production via microalgae: recent developments and future directions, Trends in Biotecnology, 28, 371-380 (2010). https://doi.org/10.1016/j. tibtech.2010.04.004

Lisboa, C.R., Pereira, A.M. and Costa, J.A.V., Biopeptides with antioxidant activity extracted from the biomass of Spirulina sp. LEB 18, African Journal of Microbiology Research, 10, 79-86 (2016). https://doi.org/10.5897/AJMR2015.7760

Lowry, O.H., Rosebrough, N.J., Farr, A.L. and Randall, R.J., Protein measurement with the Folin phenol reagent, Journal of Biological Chemistry, 193, No. 1, 265-275 (1951).

Madkour, F.F., Kamil, A.E. and Nasr, H. S., Production and nutritive value of Spirulina platensis in reduced cost media, Egyptian Journal of Aquatic Research, 38, 51-57 (2012). https://doi.org/10.1016/j. ejar.2012.09.003

Markou, G, Chatzipavlidis, I. and Georgakakis, D., Effects of phosphorus concentration and light intensity on the biomass composition of Arthrospira (Spirulina) platensis, World Journal of Microbiology and Biotechnology, 28, 2661-2670 (2012). https:// doi.org/10.1007/s11274-012-1076-4

Markou, G., Effect of various colors of Light-Emitting Diodes (LEDs) on the biomass composition of Arthospira platensis cultivated in semi-continuous mode, Applied Biochemistry Biotechnology, 172, 2758-2768 (2014). https://doi.org/10.1007/s12010014-0727-3

Martins, R.G., Gonçalves, I.S., Morais, M.G. and Costa, J.A.V., Bioprocess engineering aspects of biopolymer production by the cyanobacterium Spirulina strain LEB 18, International Journal of Polymer Science, 2014, 1-6 (2014).
Mata, T.M., Martins, A.A. and Caetano, N.S., Microalgae for biodiesel production and other applications: A review, Renewable and Sustainable Energy Reviews, 14, 217-232 (2010). https://doi. org/10.1016/j.rser.2009.07.020

Metcalfe, L.D., Schimtz, A.A. and Pelke, J.R., Rapid preparation of fatty acid esters from lipids for gas liquid chromatography, Analytical Chemistry, 38, 514-515 (1966). https://doi.org/10.1021/ ac60235a044

Monod, J., The growth of bacterial cultures, Annual Review of Microbiology, 3, 371-394 (1949). https:// doi.org/10.1146/annurev.mi.03.100149.002103

Moraes, C.C., Burkert, J.F.M and Kalil, S. J., $\mathrm{C}$-phycocyanin extraction process for largescale use, Journal of Food Biochemistry, 34, 133-148 (2010). https://doi.org/10.1111/j.17454514.2009.00317.x

Moraes, C.C., Sala, L., Cerveira, G.P and Kalil, S.J., C-phycocyanin extraction from Spirulina platensis wet biomass, Brazilian Journal of Chemical Engineering, 28, 45-49 (2011). https://doi. org/10.1590/S0104-66322011000100006

Morais, M. G. and Costa, J.A.V., Perfil de ácidos graxos de microalgas cultivadas com dióxido de carbono, Ciência e Agrotecnologia, 32, 12451251 (2008). https://doi.org/10.1590/S141370542008000400032

Morais, M.G., Radmann, E.M., Andrade, M.R., Teixeira, G.G., Brusch, L.R. and Costa, J.A.V., Pilot scale semicontinuous production of Spirulina biomass in southern Brazil, Aquaculture, 294, 60-64 (2009). https://doi.org/10.1016/j. aquaculture.2009.05.009

Morais, M.G., Reichert, C.C., Dalcaton, F., Durane, A.J., Marins, L.F. and Costa, J.A.V., Isolation and caracterization of a new Arthrospira strain, Zeitschrift fur Naturforschung, 63, 144-150 (2008). https://doi.org/10.1515/znc-2008-1-226

Moreira, J.B., Terra, A.L.M., Costa, J.A.V and Morais, M.G., Utilization of $\mathrm{CO}_{2}$ in semi-continuous cultivation of Spirulina sp. and Chlorella fusca and evaluation of biomass composition, Brazilian Journal of Chemical Engineering, 33, 691-698 (2016). https://doi.org/10.1590/0104$6632.20160333 \mathrm{~s} 20150135$

Oliveira, E.G., Rosa, G.S., Moraes, M. A. and Pinto. L.A.A., Characterization of thin layer drying of Spirulina platensis utilizing perpendicular air flow, Bioresource Technology, 100, 1297-1303 (2009). https://doi.org/10.1016/j.biortech.2008.05.052

Pelizer, L.H., Danesi, E.D.G., Rangel, C.O., Sassano, C.E.N., Carvalho, J.C.M., Sato, S. and Moraes, I.O., Influence of inoculum age and concentration in Spirulina platensis cultivation, Journal of Food Engineering, 56, 371-375 (2003). https://doi. org/10.1016/S0260-8774(02)00209-1 
Powell, N., Shilton, A.N., Pratt, S. and Chisti, Y., Factors influencing luxury uptake of phosphorus by microalgae in waste stabilization ponds, 队 Environmental Science \& Technology, 42, 59585962 (2008). https://doi.org/10.1021/es703118s

Prates, D.F., Barcia, M.T., Fanka, L.S., Radmann, E.M., Ballus, C.A., Godoy, H.T. and Costa, J.A.V., Atividade antioxidade de ficocianina extraída de Spirulina cultivada com LEDs. In: Simpósio de Bioquímica e Biotecnologia, Blucher Proceedings, Londrina (2015).

Radmann, E.M., Henrard, A.A., Rosa, A.P.C., Andrade, M.R., Morais, M.G., Zílio, R.L. and Costa, J.A.V., Cultivo de microalgas para a biofixação de $\mathrm{CO}_{2}$ e obtenção de biocombustíveis. In: Congresso Nacional do Carvão Mineral, Gramado (2011).

Radmann, E.M., Morais, E.G., Oliveira, C.F., Zanfonato, $\mathrm{K}$ and Costa, J.A.V., Microalgae cultivation for biosurfactant production, African Journal of Microbiology Research, 9, 2283-2289 (2015). https://doi.org/10.5897/AJMR2015.7634

Richmond, A., Handbook of microalgal mass culture. CRC Press, Boston (1990).

Rosa, A.P.C., Santos, T.D., Radmann, E.M., Santana, F.B. and Costa, J.A.V., Production of Spirulina in semicontinuous cultivation using medium recycle, International Journal of Engineering Research and Applications, 5, 36-42 (2015).

Santiago-Santos, M.C., Ponce-Noyola, T., OlveraRamirez, R., Ortegalópez, J. and CañizaresVillanueva, R.O., Extraction and purification of phycocyanin from Calothrix sp., Process Biochemistry, 39, 2047-2052 (2004). https://doi. org/10.1016/j.procbio.2003.10.007

Silva, C.K., Produção biotecnológica de biopolímeros aplicando processo cíclico de reutilização de resíduo da extração de poli-hidroxibutirato (PHB) (Mestrado em Engenharia e Ciência de Alimentos), Universidade Federal do Rio Grande, Rio Grande (2016).

Streit, N.M., Dinâmica de nitrogênio em cultivo heterotrófico a partir de cianobactéria sob o escopo de biorrefinarias agroindustriais (Doutorado em Engenharia e Ciência de Alimentos). Universidade Federal do Rio Grande, Rio Grande (2014).

Travieso, L., Hall, D.O., Rao, K.K., Benítez, F., Sánchez, E. and Borja, R., A helical tubular photobioreactor producing Spirulina in a semicontinuous mode, International Biodeterioration \& Biodegradation, 47, 151-155 (2001). https://doi.org/10.1016/S09648305(01)00043-9

Vonshak, A., Abeliovich, A., Boussiba, S., Arad, S. and Richmond, A., Production of Spirulina biomass: effects of environmental factors and population density, Biomass 2, 175-185 (1982). https://doi. org/10.1016/0144-4565(82)90028-2

Zarrouk, C., Contribuitional'etude Dune Cyanophycee, influence de divers facteurs physiques et chimiques sur la croissance et photosynthese de Spirulina maxima geitler, Ph.D. Thesis University of Paris (1966). 
